\title{
МЕТОДОЛОГІЯ СКОУПІНГУ В ПРОЦЕДУРАХ ОВД
}

У роботі розглянуто проблему щодо визначення обсягу та рівня деталізації дослідження у процедурах оцінювання впливів на довкілля та стратегічної екологічної оцінки. Базуючись на глибокому аналізі процедури скоупінгу міжнародних систем екологічних оцінок планованої діяльності за Інтернет-ресурсів та Інтернет-порталів, а також сучасного українського природоохоронного законодавства, автор пропонує методологію визначення обсягу та рівня деталізації дослідження у процедурах оцінювання впливів на довкілля та стратегічної екологічної оцінки.

Процес визначення обсягу та рівня деталізації дослідження у процедурах оцінювання впливів на довкілля та стратегічної екологічної оцінки є особливо важливим та найосновнішим етапом планування робіт з екологічного оцінювання проектної, планової та іншої діяльності, яка може чинити вплив на навколишнє середовище.

Визначення обсягу та рівня деталізації дослідження - скоупінг, це процес покликаний сприяти підвищенню ефективності процедурам ОВД та СЕО шляхом виявлення ключових проблем, інтересів і альтернатив, що вимагають дослідження. Ця інформація дозволить особам, відповідальним за виконання ОВД, належним чином орієнтувати дослідницьку групу на дослідження значимих проблем. Крім того, систематичне визначення завдань зменшує імовірність того, що звіт з ОВД або СЕО матиме серйозні упущення, і тим самим дозволяє уникнути затримок, пов'язаних із необхідністю переробляння звіту. Визначення завдань виконується, щоб гарантувати, що час і гроші не будуть витрачені даремно на збір непотрібних вихідних даних або виконання непотрібних досліджень, а важливі проблеми не будуть упущені.

У статті також обгрунтовано й результати скоупінгу. Автор пропонує складати технічне завдання на проведення ОВД (CEO) за результатами скоупінгу.

Ключові слова: скоупінг, оцінювання впливів на довкілля, стратегічна екологічна оцінка, екологічна оцінка, суб'єкт господарювання.

Постановка проблеми. У грудні 2017 року в Україні увійшов в дію Закон України «Про оцінку впливу на довкілля» (від 23.05.2017 р. № 2059-VIII) [1], а з березня 2018 р. - Закон України «Про стратегічну екологічну оцінку» (від 20.03.2018 р. № 2354-VIII) [2], в яких вимагається обов' язкове визначення обсягу та рівня деталізації дослідження.

Процес визначення обсягу та рівня деталізації дослідження, інакше кажучи, ключових завдань для проведення екологічних оцінок у процедурах оцінювання впливів на довкілля (ОВД) та стратегічної екологічної оцінки (CEO) $\epsilon$ особливо важливим та найголовнішим етапом планування робіт з екологічного оцінювання проектної, планової та іншої діяльності, яка може чинити вплив на навколишнє середовище.

Термін «скоупінг» походить від англомовного слова scoping. Дослівний переклад цього слова має декілька значень - діапазон, поле дій, компетенція, обсяг тощо. У вітчизняній та зарубіжній літературі термін «скоупінг» почали застосовувати в спеціалізованій літературі 3 екологічної оцінки.

У міжнародних системах екологічної оцінки скоупінг ще інакше називають визначенням сфери діяльності при проведенні екологічних оцінок, тобто скоупінг - це процедура визначення завдань, що дозволяє виявити проблеми, які, імовірно, будуть важливі для екологічних оцінок, i знімати ті, котрі не є важливими. Отже, цей етап запобігає витраті часу і грошей на непотрібні дослідження.

На цей етап розвитку системи екологічного оцінювання планованої діяльності в Україні діє єдиний реєстр ОВД Міністерства екології та природних ресурсів [3], де суб'єктом господарської діяльності згідно 3 вимогами Закону України про ОВД оголошується, наміри про плановану діяльність та будь-який громадянин нашої держави (а у разі можливого транскордонного впливу й громадяни зачепленої держави) можуть подавати свої зауваження та пропозиції до проведення подальших екологічних оцінок. 
Метою статті $\epsilon$ теоретичне обгрунтування методології визначення обсягу та рівня деталізації дослідження для процедур СЕО та ОВД. Визначення обсягу та рівня деталізації дослідження - скоупінг (англ. scoping, визначення обсягу) - це процес, покликаний сприяти підвищенню ефективності процедурам ОВД та СЕО шляхом виявлення ключових проблем, інтересів і альтернатив, що потребують дослідження. Ця інформація дозволить особам, відповідальним за виконання ОВД, належним чином орієнтувати дослідницьку групу на дослідження значимих проблем. Крім того, систематичне визначення завдань зменшує імовірність того, що звіт з ОВД (або СЕО) матиме серйозні упущення, і тим самим дозволяє уникнути затримок, пов'язаних із необхідністю переробки звіту. Визначення завдань виконується, щоб гарантувати, що час і гроші не будуть витрачені даремно на збір непотрібних вихідних даних або виконання непотрібних досліджень, а важливі проблеми не будуть упущені.

Аналіз останніх досліджень i публікацій. Процедури визначення обсягу та рівня деталізації досліджень обовязкові у багатьох розвинутих країнах світу, а також регламентовані директивами та конвенціями Євросоюзу [4-18].

У Сполучених Штатах скоупінг з'явився у відповідь на вимоги федеральних органів влади здійснювати екологічну оцінку на ранніх етапах. У деяких перших звітах з EIA (Environmental Impact Assessment) у США багато часу витрачалося на вивчення кожного зрозумілого впливу, незважаючи на його значимість, тож були підготовлені звіти такого обсягу, що важливі питання губилися за великою кількістю деталізацій. Інші роботи з екологічного впливу, навпаки, містили замало інформації та матеріалу, щоб його можна було застосувати для процесу прийняття відповідальних рішень. Аби подолати ці проблеми, існуючі в США нормативи 3 EIA були доповнені вимогами до всіх їхніх виконавців про занесення етапу визначення сфери діяльності на початок процесу екологічної оцінки.

У США, як й усіх інших розвинутих із точки зору екологічної оцінки держав, участь громадськості входить до процесу ЕІА, починаючи зі стадії скоупінгу. Це може бути виконано, якщо громадськість виявить бажання взяти участь у екологічних оцінках для певної діяльності. Залучення громадськості на ранніх етапах може сприяти більш детальній визначеності щодо чутливих екологічних ресурсів та вияву питань важливого громадського значення.

Для визначенні обсягу заходів 3 екологічної оцінки Світовий Банк рекомендує проконсультуватися не тільки з позичальником, організацією-виконавцем та технічними експертами. Цінну інформацію можуть надати державні установи, бо вони можуть визначити потенційний вплив проекту на інші галузі економіки, а ці типи впливів необхідно досліджувати. Задля цього Директива Світового Банку 4.01 рекомендує, щоб як тільки буде прийнято рішення про проведення ЕО, необхідно організовувати міжвідомчі збори, а також проводити такі збори після закінчення екологічної оцінки та іiі результати надавати на розгляд держави. На перших зборах його учасники мають домовитись про налагодження постійної координації.

У країнах Свропи і Центральної Азії використовують кілька методів скоупінгу, включаючи загальні і конкретні списки множинного вибору опцій, попередню оцінку та одержання схвалення відповідним відомством.

Викладення основного матеріалу досліджень. Максимально широкий підхід до визначення завдань може включати перелічені нижче завдання, однак на практиці не завжди необхідно, щоб визначення завдань було настільки складним.

Визначення завдань може використовуватися для того, щоб:

- розглянути розумні і реальні альтернативи;

- інформувати населення, якого може торкатися запланована діяльність та пов'язані з нею впливи;

- виявити можливі впливи на навколишнє середовище при впровадженні запланованої діяльності та їі альтернатив;

- встановити можливі впливи змін у навколишньому середовищі на людину;

- усвідомити цінність та якість навколишнього середовища для осіб і населення, яких можуть торкатися впливи при здійсненні запланованої діяльності та іiї альтернатив;

- оцінити можливі впливи на навколишне середовище для визначення необхідності i способу їхнього подальшого розгляду з урахуванням стурбованості, яка може бути виражена різними сторонами;

- визначити предмет необхідних подальших досліджень, а також просторові і тимчасові рамки, у яких будуть розглядатися впливи; 
- визначити характер необхідної подальшої оцінки, включаючи як дослідницькі роботи, так і процедури консультацій;

- систематизувати можливі впливи і проблеми, визначити серед них пріоритетні, і надати інформацію про них громадськості та зацікавленим сторонам;

- скласти технічне завдання як основу для наступного процесу екологічної оцінки.

Підхід, обраний для визначення завдань, має враховувати місцеві цінності, традиції і культуру. Необхідно, щоб відповідальність за проведення скоупінгу мав ініціатор діяльності або суб'єкт господарської діяльності, а також державні органи, що контролюють процес екологічних оцінок, або група експертів, спеціально сформована для цієї мети.

Визначення завдань потребує адекватного розгляду проекту, можливих альтернатив, ймовірних впливів, а також шляхів їхнього пом'якшення або керування ними. Необхідно визначити такі аспекти подальшого процесу ОВД (або СEО) як розглянута географічна область, тимчасові рамки для аналізу впливу, методики, які потрібно використовувати, джерела наявної інформації і пробіли в них, тривалість стадій екологічного оцінювання, а також процедуру ухвалення рішення. Мають бути чітко сформульовані пропозиції щодо участі громадськості в процесі ОВД (або СЕО) (у т.ч. на самій стадії визначення завдань).

При проведені екологічних оцінок (ЕО) важливо забезпечити концентрацію оцінки лише на важливих питаннях для різних етапів впровадження запропонованої діяльності та досить ретельно розглядати всі можливі типи впливів. Для всіх типів запропонованої діяльності важливо враховувати етапи впровадження цієї діяльності, а також етапи робіт з ЕО. У деяких випадках також необхідно розглянути етап закриття чи етап виведення з експлуатації, а у разі проектів, пов’ язаних із корисними копалинами, етап відновлення і після використання.

Неефективно використовувати кошти лише на дослідження усіх можливих впливів великого ряду альтернатив. Тому найважливішим результатом скоупінгу $є$ згода основних зацікавлених сторін, включаючи громадськість, щодо обсягу альтернатив, які слід оцінити та найважливіших впливів, які необхідно передбачити та оцінити. Скоупінг має проводити заявник діяльності, який оплачуватиме витрати.

Як мінімум до процесу скоупінгу необхідно залучити таких осіб, відомства і організації:

- міністерства та відомства, сфери відповідальності яких ймовірно будуть торкатися пропозиції (наприклад, міністерства, пов'язані з природними ресурсами, сільським господарством, транспортом, здоров'ям населення, соціальним добробутом тощо);

- місцеві державні органи влади, на територіях яких буде впроваджений запропонований проект або на території, яка ймовірно буде уражена впливами від запроектованої діяльності;

- інші державні установи, що приймають рішення (наприклад СЕС, управління земельних ресурсів, управління архітектури тощо);

- наукові установи - науково-дослідні інститути і лабораторії, галузеві інститути, заклади вищої освіти, які можуть мати вихідну інформацію про природні та техногенні чинники території, де планується впровадження діяльності;

- організації приватного сектору, такі як торговельні, комерційні, туристичні, готельні організації, ті що пов'язані з розвитком інфраструктури на території, де планується діяльність;

- неурядові громадські екологічні організації, які можуть мати інформацію про природні та соціальні чинники території, де планується впровадження діяльності;

- представників громадськості, яких ймовірно буде торкатися запланована пропозиція.

Цих осіб необхідно забезпечити інформацією про проект та його альтернативи, щоб дати їм змогу визначити питання, які їх цікавлять, а також отримати відповіді від осіб, з ким проводилися консультації.

Існує багато методів отримання відповідей. У разі державних установ та неурядових організацій можна попросити надати відповіді у письмовій формі або підчас зустрічей. Такі зустрічі можуть проходити за закритими дверима та включати замовника і ряд зацікавлених сторін. Ці зустрічі можна провести після отримання письмових коментарів, щоб прояснити питання. На першій стадії скоупінгу пропонується підготувати чорновий варіант технічного завдання.

Результати скоупінгу слід проаналізувати і оцінити та підготувати наступний варіант технічного завдання (Т3) для проведення екологічної оцінки. Як правило, замовник відповідає за процедуру скоупінгу та підготовку ТЗ, але він може найняти й консультантів для проведення цієї роботи. 
Технічне завдання - дуже важливий документ, оскільки він визначає не лише відповідність та виконання робіт з екологічного оцінювання для менеджменту проекту, а також і корисність результатів оцінки впливів на навколишнє середовище при прийнятті рішення.

Технічне завдання не слід розглядати як «фіксований» незмінний документ. У ході роботи над ОВНС може знадобитись змінити орієнтацію роботи. Необхідно досягти згоди між консультантами, замовником і відомствам, що надає дозволи до внесення змін.

Хоча визначення завдань, безумовно, є одним із ранніх етапів екологічних оцінок, подальший перегляд і коригування завдань триває протягом всієї екологічної оцінки впливів, ухвалення рішення, детального проектування, здійснення діяльності і моніторингу. Непередбачені проблеми, що потребують подальшого розгляду, можуть виникнути на кожній зі стадій ОВД (або CEO). Дослідження в рамках конкретної проблеми (наприклад, забруднення грунтових вод або зміна мікроклімату), проведені в ході екологічного оцінювання впливів, також можуть послідовно розкривати додаткові фактори або проблеми, які піднімуть питання перед групою виконавців, вкажуть потенційні сфери конфлікту між зацікавленими сторонами, вченими і широкою громадськістю.

Предметом обговорень і суперечок можуть бути питання, пов'язані з кожною сферою досліджень, такі як тип і кількість збору даних, методи їхнього аналізу, значимість і репрезентативність даних, важливість проблеми, прийняті стандарти, адекватність запропонованих заходів для пом'якшення впливів. В остаточному підсумку не існує «правильних» відповідей на ці питання, є лише послідовність суджень і рішень, спрямованих на те, щоб збалансувати доступні для дослідження ресурси (тимчасові і фінансові), 3 одного боку, i обгрунтовану стурбованість зацікавлених сторін, з іншого.

Отже, кінцевим результатом етапу скоупінгу є офіційний документ - технічне завдання, що визначає рамки робіт з ОВД (або СЕО), які організовує ініціатор. Цей документ є основою для детальної постановки завдань окремим експертам-виконавцям.

3 урахуванням наданого вище аналізу процедури скоупінгу та власний досвід автора цієї роботи, запропоновано використовувати вісім кроків для визначення сфери діяльності при проведенні екологічних оцінок (рис. 1):

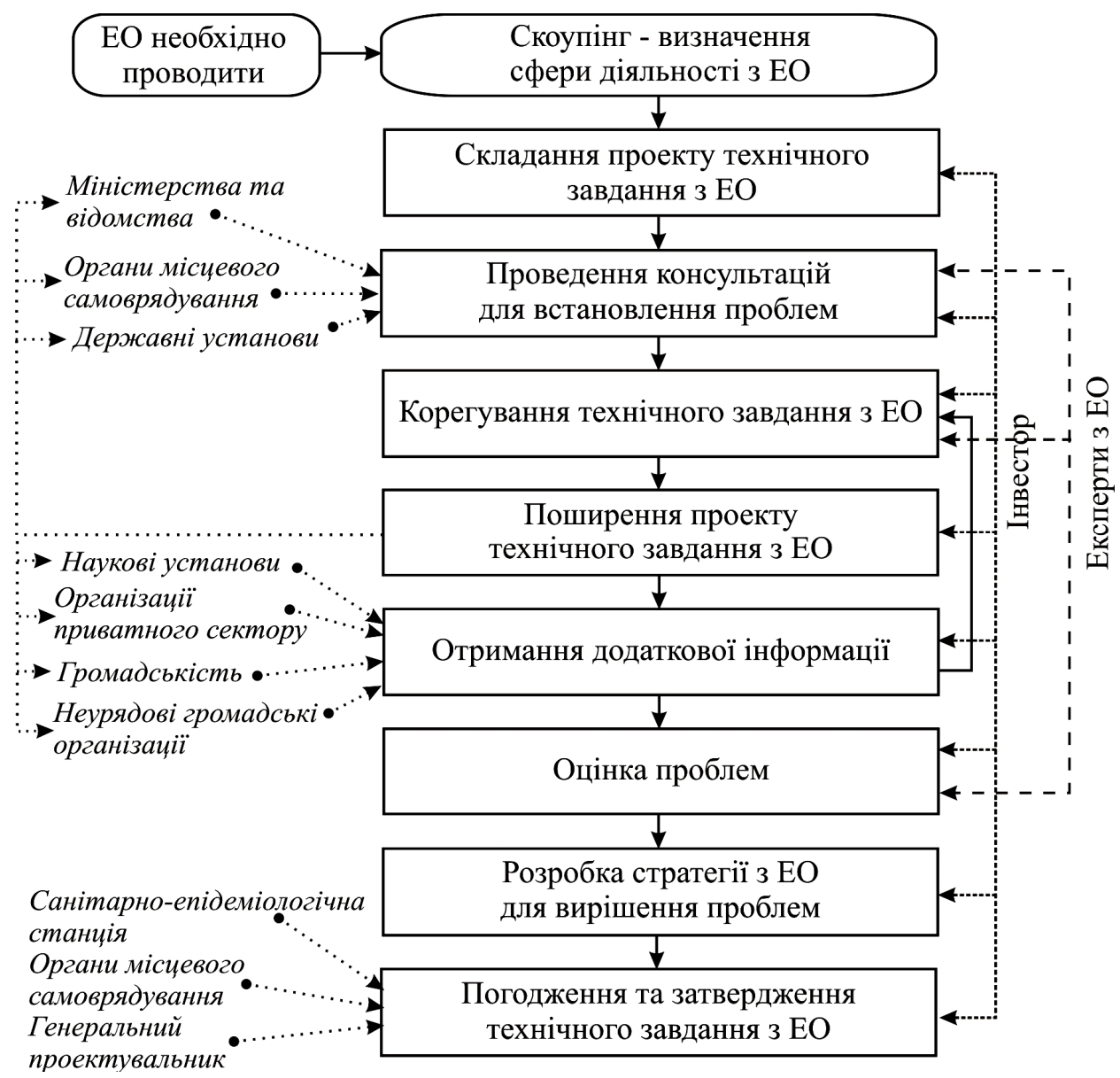

Рис. 1. Покрокова модель процедури скоупінгу 

розділами:

1. Підготувати проект (чорновий варіант) технічного завдання з ОВД (або СЕО) з такими

- мета й опис запланованої діяльності;

- умови, у яких передбачається здійснення намічуваної діяльності;

- екологічні обмеження;

- можливі реальні альтернативи;

- проблеми, що можуть бути пов'язані з впровадженням запропонованої діяльності;

- план залучення громадськості до процесу ОВД (або СЕО);

- календарний графік роботи.

2. Провести консультації 3 ініціатором, державними органами й іншими зацікавленими сторонами шляхом обговорення, збираючи доступну інформацію, виявляючи інформаційні пробіли і встановлюючи проблеми, базуючись на проробці проектного задуму.

3. Скорегувати технічне завдання з ОВД (або СЕО), враховуючи додаткову інформацію, та поширити його серед інших зацікавлених сторін, чия точка зору має бути врахована.

4. Отримати інформацію від інших зацікавлених сторін та виявити проблеми, що викликають їхню стурбованість.

5. Оцінити проблеми 3 технічної i суб'єктивної точок зору, намагаючись виявити пріоритетні проблеми.

6. Скорегувати і доповнити проект технічного завдання ОВД (або СЕО), щоб включити погоджені пропозиції.

7. Розробити стратегію для розгляду і рішення кожної з ключових проблем, включаючи потребу в інформації і технічне завдання для подальших досліджень.

8. Забезпечити зворотний зв'язок, повідомивши, яким чином були враховані коментарі i зауваження.

Висновки. Аналізуючи все вище викладене, можна констатувати, що визначення сфери діяльності запропонованого задуму є одна з найважливіших стадій процесу екологічної оцінки, бо ця процедура передбачає неодноразове визначення проблем, які можуть торкатися цієї діяльності та викликати стурбованість різних кіл зацікавлених сторін. Якщо процедуру скоупінгу проводити якомога швидше при ОВД (або СЕО), то надалі економиться не тільки бюджет проекту, але й приймають адекватне і всебічне обгрунтоване рішення з упровадження проектного задуму інвестора.

\section{Література}

1 Закон України «Про оцінку впливу на довкілля» від 23.05.2017 № 2059-VIII - Відомості Верховної Ради (ВВР), 2017, № 29 - с. 315.

2 Закон України «Про стратегічну екологічну оцінку» (від 20.03.2018 р. № 2354-VIII) Відомості Верховної Ради (ВВР), 2018, № 16 - с.138.

3 Єдиний реєстр ОВД Міністерства екології та природних ресурсів України - [Електронний pecypc] - Режим доступу: http://eia.menr.gov.ua/

4 Brazil - ECOFORCE [інтернет-портал]. - http://www.ecof.org.br.

5 Canadian Environmental Assessment Agency (CEAA). [інтернет-портал].http://www.ceaa.gc.ca. $43 \mathrm{pp}$.

6 Couch W. J. The Canadian Guide to Environmental Assessment Abroad. - Canada, 1993. -

7 EIA Centre, Hamm, Germany. [інтернет-портал]. - http://www.laum.uni-hannover.de.

8 EIA Centre, Roskilde, Denmark. [інтернет-портал]. - http://www.teksam.ruc.dk.

9 EIA Section, DGXI, European Commission. [інтернет-портал].- http://europa.eu.int.

10 EIA Unit - University of Wales, Aberystwyth. [інтернет-портал]. - http://www.aber.ac.uk.

11 Environment Agency, Government of Japan. [інтернет-портал]. - http://www.eic.or.jp.

12 European Bank for Reconstruction and Development. Environmental Procedures. European Bank for Reconstruction and Development. - London. - UK, 1992. - 4 pp..

13 Hong Kong Environmental Protection Department, EIA page. [Електронний ресурс] http://www.info.gov.hk/epd/eia.

14 Impacts Assessment Unit, Oxford. [інтернет-портал]. - http://www.brookes.ac.uk.

15 Institute of Environmental Management and Assessment, Lincoln, UK. [Електронний ресурс] - http://www.iema.net. 
16 Mexican EIA. [інтернет-портал]. - http://www.ine.gob.mx.

17 The Essex guide to Environmental Impact Assessment // Peter Hakes, DMS FRTPI Chair of Environmental Assessment Working Party Essex County Council, Planning Division, County Hall Chelmsford Essex. - UK, 2000. - 105 pp.

18 US EPA Databases and Software. [інтернет-портал]. - http://www.epa.gov.

\section{Ya. Adamenko}

Ivano-Frankivsk National

Technical University of Oil and Gas

\section{SCOPING METHODOLOGY IN EIA PROCEDURES}

The paper considers the problem of determining the scope and level of detail of the study in the procedures of environmental impact assessment (EIA) and strategic environmental assessment (SEA). Based on the deep analysis of the scoping process in the international environmental assessment systems of planning activities according to Internet resources and Internet portals as well as the modern Ukrainian environmental legislation, the author proposes a methodology for determining the scope and level of detail of the study in the procedures of environmental impact assessment and strategic environmental assessment.

The process of determining the scope and level of detail of the research in the procedures of environmental impact assessment and strategic environmental assessment is very important. It is the key stage in planning the environmental assessment, in project, planning and other activities, which may impact the environment.

Determining the scope and level of detail of the study is scoping, a process designed to enhance the effectiveness of EIA and SEA procedures by identifying key issues, interests and alternatives that require research. This information will help those, responsible for the implementation of environmental impact assessment, to properly focus the research group on studying significant issues. In addition, the systematic identification of tasks reduces the likelihood that the EIA and SEA report will have serious omissions and thereby helps to avoid delays associated with the need to rewrite the report. Task definition is performed to ensure that time and money will not be wasted on collecting unnecessary raw data or performing unnecessary research, and important issues will not be missed.

The article also substantiates the results of scoping. The author proposes to develop the requirements specification for conducting the EIA and SEA procedures based on scoping results.

Key words: scoping, environmental impact assessment, strategic environmental assessment, environmental assessment, business entity.

\section{References}

1 Zakon Ukraïni «Pro ocinku vplivu na dovkillya» (vid 23.05.2017 № 2059-VIII) - Vidomosti Verhovnoï Radi (VVR), 2017, № 29 - s.315.

2 Zakon Ukraïni «Pro strategichnu ekologichnu ocinku» (vid 20.03.2018 № 2354-VIII) Vidomosti Verhovnoï Radi (VVR), 2018, № 16 - s.138.

3 Cdinij reestr OVD Ministerstva ekologiï ta prirodnih resursiv Ukraïni - [Elektronnij resurs] Rezhim dostupu: http://eia.menr.gov.ua/

4 Brazil - ECOFORCE [internet-portal]. - http://www.ecof.org.br.

5 Canadian Environmental Assessment Agency (CEAA). [internet-portal].http://www.ceaa.gc.ca.

6 Couch W. J. The Canadian Guide to Environmental Assessment Abroad. - Canada, 1993. $43 \mathrm{pp}$.

7 EIA Centre, Hamm, Germany. [internet-portal]. - http://www.laum.uni-hannover.de.

8 EIA Centre, Roskilde, Denmark. [internet-portal]. - http://www.teksam.ruc.dk.

9 EIA Section, DGXI, European Commission. [internet-portal].- http://europa.eu.int.

10 EIA Unit - University of Wales, Aberystwyth. [internet-portal]. - http://www.aber.ac.uk.

11 Environment Agency, Government of Japan. internet-portal]. - http://www.eic.or.jp.

12 European Bank for Reconstruction and Development. Environmental Procedures. European Bank for Reconstruction and Development. - London. - UK, 1992. - 4 pp.

13 Hong Kong Environmental Protection Department, EIA page. [Elektronnij resurs] http://www.info.gov.hk/epd/eia. 
14 Impacts Assessment Unit, Oxford. [internet-portal]. - http://www.brookes.ac.uk.

15 Institute of Environmental Management and Assessment, Lincoln, UK. [Elektronnij resurs] http://www.iema.net.

16 Mexican EIA. [internet-portal]. - http://www.ine.gob.mx.

17 The Essex guide to Environmental Impact Assessment // Peter Hakes, DMS FRTPI Chair of Environmental Assessment Working Party Essex County Council, Planning Division, County Hall Chelmsford Essex. - UK, 2000. - 105 pp.

18 US EPA Databases and Software. [internet-portal]. - http://www.epa.gov.

Надійшла до редакиії 7 травня 2019 р. 